\title{
本郷邦広 学位論文審査要旨
}

$\begin{array}{ccccc}\text { 主査 } & \text { 畠 } & & \text { 義 } & \text { 郎 } \\ \text { 副主査 } & \text { 押 } & \text { 村 } & \text { 光 } & \text { 雄 } \\ \text { 同 } & \text { 河 } & \text { 田 } & \text { 康 } & \text { 志 }\end{array}$

\section{主論文}

Varied effects of Pyrococcus furiosus prefoldin and P. furiosus chaperonin on the refolding reactions of substrate proteins

(基質タンパク質のリフォールディング反応におけるピロコッカス フリオサス プレフ オルディンとシャペロニンの様々な影響)

(著者 : 本郷邦広、板井啓、溝端知宏、河田康志)

平成24年 The Journal of Biochemistry 掲載予定 


\section{学 位 論文要 旨}

Varied effects of Pyrococcus furiosus prefoldin and $P$. furiosus chaperonin on the refolding reactions of substrate proteins

（基質タンパク質のリフォールディング反応におけるピロコッカス フリオサス プレフォ ルディンとシャペロニンの様々な影響）

プレフォルディンは古細菌と真核生物の細胞質で発見された分子シャペロンである。プ レフォルディンは、タンパク質合成直後のポリペプチド鎖に結合したり、細胞骨格タンパ ク質が非天然構造になった場合に一時的に結合して安定化に寄与し、正しい折りたたみ構 造を形成するようにグループII型シャペロニンに引き渡す。しかし、その詳細なメカニズ ム、特に同じ生物種由来の基質タンパク質に対する作用機序は明らかになっていない。そ こで、本研究においてはPyrococcus furiosus シャペロニン (PfuCPN) 存在下、P. furiosus クエン酸合成酵素（PfuCS）とオワンクラゲ 緑色蛍光タンパク質 (GFPuv) それぞれのリフ オールディング反応中におけるP. furiosus プレフォルディン（PfuPFD）の影響を検討し た。その結果、PfuPFDとPfuCPN両方が、PfuCSあるいはGFPuvのリフォールディング中間体 と相互作用し得ることが明らかになった。しかしながら、これらの分子シャペロンと基質 タンパク質との相互作用はそれぞれの場合で異なっており、リフォールディング反応後の 活性回復率に与える影響は様々であった。すなわち、基質タンパク質によってPfuPFDとの 相互作用メカニズムは異なり、それぞれのタンパク質の特徴に応じた分子シャペロンがフ オールディングに関与すると考えられる。

\section{方 法}

PfuCPN、PfuPFD、PfuCS各遺伝子は特異的プライマーを用いてPCR増幅させてタンパク質 発現ベクターに連結した。作成したタンパク質発現ベクターを保持した大腸菌に組換えタ ンパク質を発現させ、それぞれのタンパク質の精製を行った。GFPuvも市販のタンパク質発 現ベクターを保持した大腸菌を用いて発現と精製を行った。PfuPFD とPfuCPNのシャペロン 活性は、変性GFPuvとPfuCSのリフォールディング実験によってそれぞれの活性回復率を測 定して評価した。さらにPfuCPN については、ATP加水分解活性とネイティブPfuCSに対する 熱変性保護効果も評価した。

\section{結 果}

PfuCPNはゲルろ過分画後、動的光散乱光度計を用いてPfuCPNの高次構造を評価すること で16量体PfuCPNとして精製した。このPfuCPNは、Mg ${ }^{2+}$ 存在下でATP加水分解活性を示し、 Mg-ATP依存的に酸変性GFPuvのリフォールディングを促進した。しかし、PfuPFDはPfuCPN の有無に関わらず、酸変性GFPuvのリフォールディングを抑制した。一方、PfuCSのリフォ 
ールディング反応ではGFPuvとは対照的に、PfuCPN単独ではPfuCSの活性回復に関与できな かった。しかしながら、PfuPFDが存在する場合にはPfuCSは顕著に活性回復し、PfuPFDが PfuCSのリフォールディングを補助することが明らかになった。

\section{考 察}

PfuCPNはGFPuvリフォールディング中間体と結合し、Mg-ATP依存的に活性を回復させるこ とは可能であったが、PfuCSのリフォールディングには関与できなかった。しかし、PfuCPN はネイティブPfuCSを熱変性から保護することが可能であったことから、PfuCSフォールデ イング中間体と相互作用する能力は維持していると考えられる。一方、PfuPFDの存在下で はPfuCsのリフォールディングを促進可能であった。しかしながら、PfuCPNを共存させると むしろ活性回復率は低下した。これは、PfuCPNがATP非存在下でGFPuvリフォールディング 中間体と安定な複合体を形成し、Mg-ATP依存的に解離してリフォールディングを促進した が、PfuPFD存在下では活性回復を抑制した結果と相反するものであった。これらの結果は、 GFPuv リフォールディング中間体はPfuCPNよりもPfuPFDと結合しやすく、PfuCSリフォール ディング中間体はこれらの分子シャペロンと競争的に結合することを示唆している。すな わち、これらの分子シャペロンとタンパク質フォールディング中間体との相互作用はそれ らの結合親和性によって支配されており、その相違はタンパク質のフォールディング速度 や分子表面の特性の影響を受けていると考えられる。

\section{結 論}

PfuPFD とPfuCPNは、基質タンパク質PfuCS とGFPuvそれぞれのリフォールディング中間体 と相互作用可能であった。しかし、これらの分子シャペロンが基質タンパク質のリフォー ルディングに与える影響は異なっており、基質タンパク質と分子シャペロンとの相互作用 の違いによってシャペロン効果に差が生じることが明らかになった。今後、各種基質タン パク質と分子シャペロンとの相互作用が網羅的に解析されることによって、細胞内のタン パク質品質管理機構の詳細が明らかになることが期待される。 